\title{
Indigenous Participation in Intercultural Education: Learning from Mexico and Tanzania
}

\author{
Gemma Burford $^{1,2}, \underline{\text { Susanne Kissmann }}^{3}, \underline{\text { Francisco J. Rosado-May }}^{3}$, Santos H. Alvarado Dzul ${ }^{3}$ and Marie K. Harder ${ }^{1,4}$
}

\begin{abstract}
Intercultural education seeks to create a forum for integrating Western scientific knowledge and indigenous knowledge to address local and global challenges such as biocultural diversity conservation, natural resource management, and social justice for indigenous peoples. Intercultural education is based on learning together with, rather than learning about or from, indigenous communities. In the best examples, problem-based learning dissolves the dichotomy between indigenous and nonindigenous, resulting in full partnerships in which participants share expertise to meet mutual needs. With reference to literature and two illustrative examples of intercultural education initiatives in Mexico and Tanzania, we present an original conceptual framework for assessing indigenous participation in intercultural education. This incorporates a new ladder of participation depth (in relation to both curriculum content and decision making) alongside separate considerations of breadth, i.e., stakeholder diversity, and scope, i.e., the number of key project stages in which certain stakeholder groups are participating. The framework can be used to compare intercultural education initiatives in differing contexts and might be adaptable to other intercultural work.
\end{abstract}

Key Words: community engagement; community-university partnerships; indigenous knowledge; intercultural education; participation

\section{INTRODUCTION}

In light of the urgent need for sustainable and effective natural resource management, both locally and globally, there is an increasing recognition of the importance of creating fora to integrate indigenous knowledge (IK) and Western scientific knowledge (e.g., Berkes et al. 2000, Romero and Peña-Claros 2009, Bohensky and Maru 2011). These terms persist within academic literature and professional practice, despite earlier observations that they are widely contested (Ellen 1998, Sillitoe 1998), have multiple synonyms and conflicting definitions (Agrawal 1995, Bohensky and Maru 2011), and cannot always be clearly delineated (Agrawal 1995). Ellen (1998:238) provides a useful working definition of IK as "local, orally transmitted, a consequence of practical engagement reinforced by experience, empirical rather than theoretical, repetitive, fluid and negotiable, shared but asymmetrically distributed, largely functional, and embedded in a more encompassing cultural matrix." For brevity, we use the term "science" to encompass Western scientific systems of knowledge, both pure (biology, chemistry, physics) and applied (environmental sciences, agricultural science, etc.), as widely taught in formal curricula throughout the industrialized world.

Here, we develop an original conceptual framework of indigenous participation in education by relating established concepts of participation and partnership, drawn from diverse fields of academic literature, to two contrasting examples of intercultural education programs, in Mexico and Tanzania, respectively. These examples are derived from reflexive documentation of our own experiences as practitioners and participant-observers, supplemented by document analysis, unstructured interviews, and informal conversations with colleagues. Our framework consists of three dimensions: (1) depth of participation, which in turn can be broken down into curriculum content and control over decision making; (2) breadth of participation, i.e., diversity of stakeholders; and (3) scope of participation, which relates to the number of key stages in which a particular stakeholder is involved. We suggest that this framework might be useful in facilitating comparison and mutual learning across intercultural education initiatives, and that beyond the specific context of education, it may be usefully adapted to other arenas of intercultural work.

The term "intercultural education" has been used in Latin America for decades to refer to educational systems that seek mutual exchange between different bodies of knowledge while perceiving them as equal in status (e.g., science is not privileged over IK). An intercultural education initiative entails productive two-way dialog, generating something novel at the interface between IK and science (Schroder 2006). It incorporates processes such as the promotion of dialog and equal relations between an indigenous and a dominant society (Aikman 1998); the elimination of prejudice and stereotyping; and the strengthening of democracy (Aikman 1998; see also

${ }^{1}$ University of Brighton, ${ }^{2}$ Aang Serian (House of Peace), ${ }^{3}$ Universidad Intercultural Maya de Quintana Roo, ${ }^{4}$ Fudan University 
Bodnar 1990; Aikman 1997; Gundara 2000). Intercultural education has been made widely mainstream in the formal tertiary education sector in Latin America, in diverse national programs, and even in a regional collaboration among five Andean countries (Pedota 2011; see also García 2005, Schmelkes 2009). In Africa, however, only isolated examples exist (e.g., Cross 2004, Carignan et al. 2005).

Intercultural education initiatives may have diverse and interrelated goals, some explicit and others tacit. Some can be linked to arguments in favor of integrating IK and science, described by Bohensky and Maru (2011). First, knowledge integration is believed to contribute to the conservation of biological, cultural, and linguistic diversity, collectively called biocultural diversity, a process in which appropriate education plays an integral role (Maffi 2001, Maffi and Woodley 2010). Second, the complementarity between IK and science has been widely used in adaptive co-management of natural resources, i.e., shared management by different stakeholders on the basis of mutual learning, for which intercultural education may be critical (e.g., Klooster 2002, Reed and Dougill 2002, Moller et al. 2004, Armitage et al. 2008, Kainer et al. 2009, Romero and Peña-Claros 2009). Third, knowledge integration has social justice implications such as affirming the autonomy, sovereignty, and identity of indigenous communities. Intercultural education has been claimed to improve the equity of relations between indigenous and dominant societies; to reduce prejudice and stereotyping; to strengthen democracy; and to assist nonindigenous actors to accept social and environmental responsibilities (Agrawal 1995, Aikman 1997, 1998, Gundara 2000, Murphy-Graham 2007, Honeyman 2010).

Intercultural education is not merely the process of learning about indigenous societies while reinforcing discourses of traditionality, e.g., by writing about the respective societies in the past tense, implying homogeneity of culture, and perpetuating racist stereotypes (Campbell and Marshall 2003, Ninnes 2000). Nor is it equivalent to learning from indigenous societies while still using deprecatory terminology and implicitly accepting the superiority of the nonindigenous (e. g., Ojating 1997). Rather, the ideal of intercultural education is to dissolve dichotomies between cultural groups, illustrate common challenges facing humanity, and empower participants to address these challenges by creating new, shared knowledge and world views (Aikman 1998). Intercultural education can thus be understood as a new stage in the evolution of relations between indigenous and nonindigenous societies, which we describe as learning together.

\section{Dimensions of a participation framework}

A principal foundation of intercultural education is meaningful participation, a subject that is increasingly creating an interface among academic disciplines. Conventional disciplinary boundaries often obscure the commonalities between such emerging fields as adaptive (co)-management of natural resources (Ruitenbeek and Cartier 2001, Klooster 2002, Moller et al. 2004), participatory community planning (Chambers 1997), community-based participatory research (Cornwall and Jewkes 1995, Powers et al. 2006), and participatory monitoring and evaluation (Crishna 2007). The concept of participation as a continuum, for example, is separately described in the respective contexts of adaptive management by Taiepa et al. (1997), participatory monitoring and evaluation by Cousins et al. (1996), and community-based participatory research by Naylor et al. (2002), yet these authors do not cite one another.

The idea of a ladder of participation, ranging from tokenistic consultation at one extreme, through stages of cooperation and partnership, to full control of decision making and ownership of the process by local stakeholders at the other, was first described by Arnstein (1969). Different typologies of the depth of participation (i.e., the extent of local ownership and control) have since been proposed by Biggs (1989), Hart (1992), Hanley et al. (2004), and most recently, Daigneault and Jacob (2009), who apply a quantitative rating scale to measure participation depth by focusing specifically on control over decision making. These typologies can provide new insight into the literature on indigenous participation in education. If a learning-about-indigenous-societies approach constitutes participation at its most superficial level, and learning from indigenous societies can be regarded as an intermediate level, intercultural education as learning together exemplifies a deep level of participation in which the process in question is not imposed upon indigenous communities but co-designed with them.

It is important to note that participation is dynamic in nature: The extent of involvement of a particular stakeholder or group of stakeholders can vary throughout the life cycle of a program (Naylor et al. 2002, Daigneault and Jacob 2009). By identifying key decision-making stages within a program, it is possible to quantify not only the depth of participation at each stage (Naylor et al. 2002), but also the number of key stages in which certain stakeholders are participating (Daigneault and Jacob 2009). Here, we refer to the "number of key stages" indicator as the scope dimension of participation, although Daigneault and Jacob (2009:338) call this "extent of involvement".

A further dimension is the breadth of participation within a community, which ranges from "restriction to primary users" to "inclusion of all legitimate groups" (Cousins and Whitmore 1998:10). The assumption that one or a few people can adequately represent the views of a whole community has been widely challenged (Cornwall and Jewkes 1995; see also Castleden et al. 2008, MacLean et al. 2009), and a study of participatory health research in Native American communities 
highlights the challenges of sustaining deep levels of participation among a broad stakeholder population (Peterson 2010). While breadth, like depth, is best characterized as a continuum (Cousins et al. 1996), it is possible to quantify it by identifying possible categories of stakeholders and asking how many of them are actually represented in a given program (Daigneault and Jacob 2009). We use our examples to identify relevant categories of stakeholders associated with intercultural education initiatives.

Finally, the quality of the participatory process requires consideration. Although Arnold and Fernandez-Gimenez (2007:483) use the term "quality" to encompass both participation breadth and "the sincerity and thoughtfulness of participant engagement", we suggest that quality is a separate dimension from breadth and the two should not be conflated. Intangible attributes such as sincerity are difficult to quantify; although some progress has been made recently in developing methodologies for measuring ethical and spiritual values (Podger et al. 2010, Burford et al. 2013), a detailed examination of such approaches is beyond the scope of this paper. Thus, without diminishing the importance of sincerity and thoughtfulness, we present an initial conceptual framework focusing on the tangible dimensions of depth, scope, and breadth.

\section{Community-university partnerships: co-creation of knowledge}

Further relevant insights can be drawn from another emerging area of study that examines the growing trend for universities and communities to establish partnerships based on a joint program of work that "meets mutual needs and draws on mutual experience and expertise" (University of Brighton, unpublished manuscript, cited in Laing and Maddison 2007:16; see also Hart et al. 2007). Although the term "community-university partnerships" has arisen out of research in the United Kingdom, United States, and Australia, the concept itself bears many similarities to the Latin American model of intercultural universities (Pedota 2011). Such partnerships can result in the generation of a distinctive mode of knowledge, which is simultaneously problem-based, change-oriented, heterogeneous, transdisciplinary, peerreviewed, and crucially, co-produced by the university and the community (Gibbons et al. 1994, Hart et al. 2007). As defined by Boud and Feletti (1998), problem-based learning is an approach in which the curriculum is centered around key problems in professional practice, rather than starting from disciplinary knowledge.

We suggest that this type of learning partnership can be viewed as the culmination of indigenous participation in education. It represents a stage in which dichotomies between indigenous and nonindigenous actors are erased through a focus on problem-based learning for biocultural diversity conservation and/or natural resource management. This creates a community of co-learners, contributing their respective insights toward the accomplishment of mutually agreed goals.

\section{ILLUSTRATIVE EXAMPLES}

\section{Intercultural Maya University of Quintana Roo, Mexico}

\section{Context}

As in other parts of Mexico, conservation failures in Quintana Roo are evident from a significant annual biodiversity loss that threatens ecosystem resilience (Geoghegan et al. 2001, Schmook and Vance 2009). In line with national policies, the state has both a system of Natural Protected Areas and a parallel natural resource management system based on ejidos, which are communities with a system of cooperative land tenure (Assies 2008). Ejidos represent $80 \%$ of the state's local forest resources and are largely composed of indigenous populations (Primack et al. 1999). Whereas management of Natural Protected Areas is guided by the Western concept of carrying capacity, indigenous ejidos rely on concepts such as $K a$ 'anan Kax, or care of the forest for future use, in which management includes a larger world view of the human community as an integral part of the natural community. In ejidos, natural resource management is accompanied by a system of social support and participation by various community stakeholders (e.g., Ellis and Porter-Bolland 2008), and strategic decisions are made according to the community's perception of environmental changes and the needs generated by climatic conditions (de Janvry et al. 1991). In spite of the growing recognition that indigenous ejidos can be as effective as protected areas in preventing deforestation, and sometimes even more so (Primack et al. 1999, Ellis and Porter-Bolland 2008), most of the training for policy makers in natural resource management in Quintana Roo remains biased toward the Western scientific system of knowledge construction.

In 2001, the second article in Mexico's national constitution was revised to recognize indigenous heritage as fundamental to the identity of the nation. This substantially changed the State's relationship to indigenous communities, recognizing them as active rather than passive players in society, and laid the foundations for the Intercultural University System. The intercultural model provides fora to bring together the Western scientific knowledge of conventional universities and the indigenous knowledge of Mexico's various ethnic groups to expand possibilities for equitable and sustainable development (Casillas-Muñoz and Villar 2006, Schmelkes 2009). The Intercultural Maya University of Quintana Roo (UIMQRoo) is the seventh of eleven intercultural universities established in areas with high concentrations of indigenous populations throughout the country.

\section{Description of the program}

The underlying theoretical assumption of the UIMQRoo educational model is that there are different forms of learning 
and thus different systems of construction of knowledge (Aguilar Pérez and Ortega Pérez 2008, Pérez Tamayo 1998). Their coexistence and interaction can provide a legitimate space to generate new knowledge and strategies for addressing local and global challenges. An example is the creation of the field of agroecology by integrating conventional ecology with Mayan knowledge of traditional agricultural systems (Gliessman 2007).

Institutionalizing the intercultural model is achieved through various policies and practices. Trans-disciplinary collaborations between faculty members are strongly encouraged, and each course provides space to examine the subject from an intercultural perspective. Because language reflects the knowledge, values, and concepts of a culture, all undergraduate students take at least two years of Maya, the language in which the local culture constructs its knowledge, as well as two years of English as the international language of scientific communication. A cornerstone of the model is the Community Linkages Course, taught during summer semesters, in which students apply insights and knowledge gained through the lens of interculturality during earlier semesters. Students work on sustainable development projects in rural communities (often their own), and can either choose to adopt a participatory action research methodology (Rodríguez Gabarrón and Hernández Landa 1994, Ataöv et al. 2010; see also Bradbury-Huang 2010) or a conventional academic approach. Project development is a collaborative process in which students, faculty, and community members share their respective experiences and expertise to ensure that the projects address local needs and challenges. Field experiences are often incorporated into teaching or further research.

The extent of local ownership of the UIMQRoo educational process is evident from its three distinct approaches to incorporating indigenous knowledge. First, community members selected on the basis of knowledge and experience are engaged as members of key committees, whose roles include hiring faculty, selecting students for admission, and assessing student theses. Second, sabios locales, or local wise persons, recognized by the community for their knowledge of a particular area, participate in teaching and are encouraged to collaborate in student and faculty-led research. They have recently been accorded the same status within the university as conventionally trained faculty members. In the first year of the required summer field course, students write personal histories about individual sabios locales, who in turn become a potential resource for their projects. A third opportunity for the integration of local knowledge is provided by abuelos(as) tutores, or mentoring elders, selected by each new student on enrollment to guide him or her in learning the Maya language and appropriate behavior in community settings. University professors who teach Maya take into account the opinion of abuelos(as) tutores in assigning grades.

\section{Outcomes}

Data indicate promising potential positive effects of the UIMQRoo educational model on sustainable development and resource management policies and practices in the region. For example, among the first graduating class in 2011 in the area of agroecology, all 44 student research or development projects (defined with community input) were directly linked to conservation or sustainable development topics. These included analysis and implementation of environmental and conservation policies (9\%), environmental education (14\%), agroecological production of local species $(33 \%)$, and documenting, promoting, or building upon traditional production practices or uses of plants and animals (44\%). The majority of these projects (56\%) involved substantial use of local knowledge. Of the 105 graduates across all courses, 52\% have already found employment, all in the public sector, and 73\% of those employed report moderate to extensive application of the knowledge they acquired at university.

\section{Noonkodin Secondary School, Monduli, Tanzania}

\section{Context}

In Tanzania, colonial perceptions of conservation as the construction of a dehumanized African wilderness have promoted dispossession of local communities from ancestral lands (Adams and McShane 1992). The Maasai are the most severely affected ethnic group, with an estimated $59 \%$ of the Maasai Steppe ecosystem under conservation management regimes, and $30 \%$ comprising protected areas from which people are excluded (Sachedina 2008). Although communitybased conservation has become fashionable in recent years, attracting large-scale funding from bilateral donors (notably USAID) and international nongovernmental organizations such as the African Wildlife Foundation and Frankfurt Zoological Society, it has been suggested that these programs may not be all that they seem. Sachedina (2008), for example, criticizes the African Wildlife Foundation for creating an illusion of local support for conservation projects that are in reality highly unpopular while also concentrating wildlife tourism revenues in the hands of local elites (see also Igoe and Croucher 2007, Fine 2008, Igoe 2010). Goldman (2001) comments that the current community-based conservation structure in the Maasai ecosystem focuses on education and training from a Western scientific perspective while neglecting indigenous knowledge.

Post-independence policies in Tanzania strongly promoted national unity and a modernist vision of development, attempting to eliminate ethnic differences by law. Pastoralist and hunter-gatherer communities were criticized for holding the country back (Ivaska 2004), and forced resettlement of 
Maasai into socialist agricultural villages (Ndagala 1982, Scott 1998) was accompanied by unsuccessful attempts to outlaw their distinctive style of dress (Ivaska 2004, Schneider 2006). The influence of Christianity (Burford 2002, Hodgson 2005) and the loss of livestock to disease (McCabe 2003) also contributed to transitions from pastoralism toward other subsistence strategies such as agriculture, tourism, and urban employment. Formal education continues to emphasize nonindigenous knowledge while preventing Maasai youth from participating in indigenous educational activities, resulting in alienation from cultural norms and values (Håkansson 2001) and the loss of context-specific ecological knowledge (Becht and Ho 2009).

\section{Description of the program}

Noonkodin Secondary School, located in a Maasai-dominated rural district of Tanzania, was established by the nongovernmental organization Aang Serian (House of Peace) to bridge the gap between indigenous and Western knowledge, worldviews, and pedagogies, and to conserve biocultural diversity (Burford et al. 2003, Burford and Ole Ngila 2006, FitzGerald 2008). The school currently has approximately 230 students, mainly in the 14-18 age range, although there is a sizeable minority of mature students. Alongside the Tanzanian national secondary curriculum, Noonkodin offers a structured but nonexamined co-curricular program in which participants learn the histories, oral literature, traditional cultural practices, and ethnobotanical knowledge of their respective ethnic groups. Course topics were selected through a multi-year process of consultation between indigenous and nonindigenous members of Aang Serian (United Nations Environment Program 2003).

Regular seminars are based on interactive discussions, led by a trained facilitator, in which learning is achieved through the exchange of ideas and experiences. However, an integral part of the Noonkodin co-curricular program is student-led field research (Burford et al. 2003, Burford and Ole Ngila 2006). After training in interviews and freelist analysis (Martin 2004), the students conduct their own investigations in neighboring communities, interviewing parents and other local elders. In one such project in August 2009, students compared the knowledge of their peers with that of community elders with respect to the preparation and uses of five salient medicinal plants. The results showed that local students possessed only $48 \%$ of the knowledge held by community elders about the five plants, and nonlocal students as little as $37 \%$ (Becht and Ho 2009). Although in this analysis it was difficult to disaggregate the effects of knowledge erosion from normal age-related effects (see also Zent 2001), local elders also reported in interviews that both breadth and depth of ethnobotanical knowledge among youth had declined in comparison with that of earlier generations.
In response to these findings, the focus of the Noonkodin student field program has shifted toward the large-scale documentation of Maasai health traditions. The Maasai Medicines Documentation Program has been established as a multi-year collaboration between Noonkodin School, the Traditional Medicine Research Department of Tanzania's National Institute for Medical Research, Luther College (Decorah, Iowa, USA), and Osero Forest Clinic and African Living Spa (Bodeker and Burford 2008), an integrated health facility owned and operated by a safari lodge in Ngorongoro, Tanzania. The project was co-designed by stakeholders from all participating institutions. Its aim is to collect information on the uses, formulations, and conservation status of local medicinal plant species. The knowledge of these plants is acknowledged as the intellectual property of the participating Maasai communities, and dissemination of findings will be restricted to project partners and named community representatives, who will receive training in access and benefit-sharing issues. The expertise of Luther College students, National Institute for Medical Research staff, and Osero healers is used to build capacity among Noonkodin students and graduates. A laboratory research project has been initiated to explore the feasibility of developing soaps and skin creams from sustainably harvested medicinal plants.

\section{Outcomes}

An important outcome for biocultural diversity conservation is the documentation of 20 medicinal plants in a booklet incorporating color photographs, plant descriptions, detailed information on preparations and uses (including dosage, cautions, and side-effects), and other relevant details. This ongoing activity generates not only a permanent written record of indigenous health knowledge, but also a comprehensive praxis-based training program for participating students. Several promising product samples have been obtained through laboratory studies, although production has yet to be scaled up.

An evaluation of the Noonkodin program was recently initiated, using a values-based indicators approach (Podger et al. 2010, Burford et al. 2013) to compare the values, attitudes, and behavior of Noonkodin students with those of students at two mainstream secondary schools. Preliminary results are encouraging, suggesting that Noonkodin students are learning to challenge stereotypes, think critically, and construct new knowledge to address sustainability challenges. The school headmaster commented in an unstructured interview on the high standards of discipline and the atmosphere of harmony and mutual understanding among the students, which he attributed to the intercultural awareness raised by the cocurricular program. We acknowledge, however, that there may be alternative explanations such as cultural factors, the remote location of the school, or the individual personalities of senior 
Fig. 1. A ladder of indigenous participation in intercultural education.

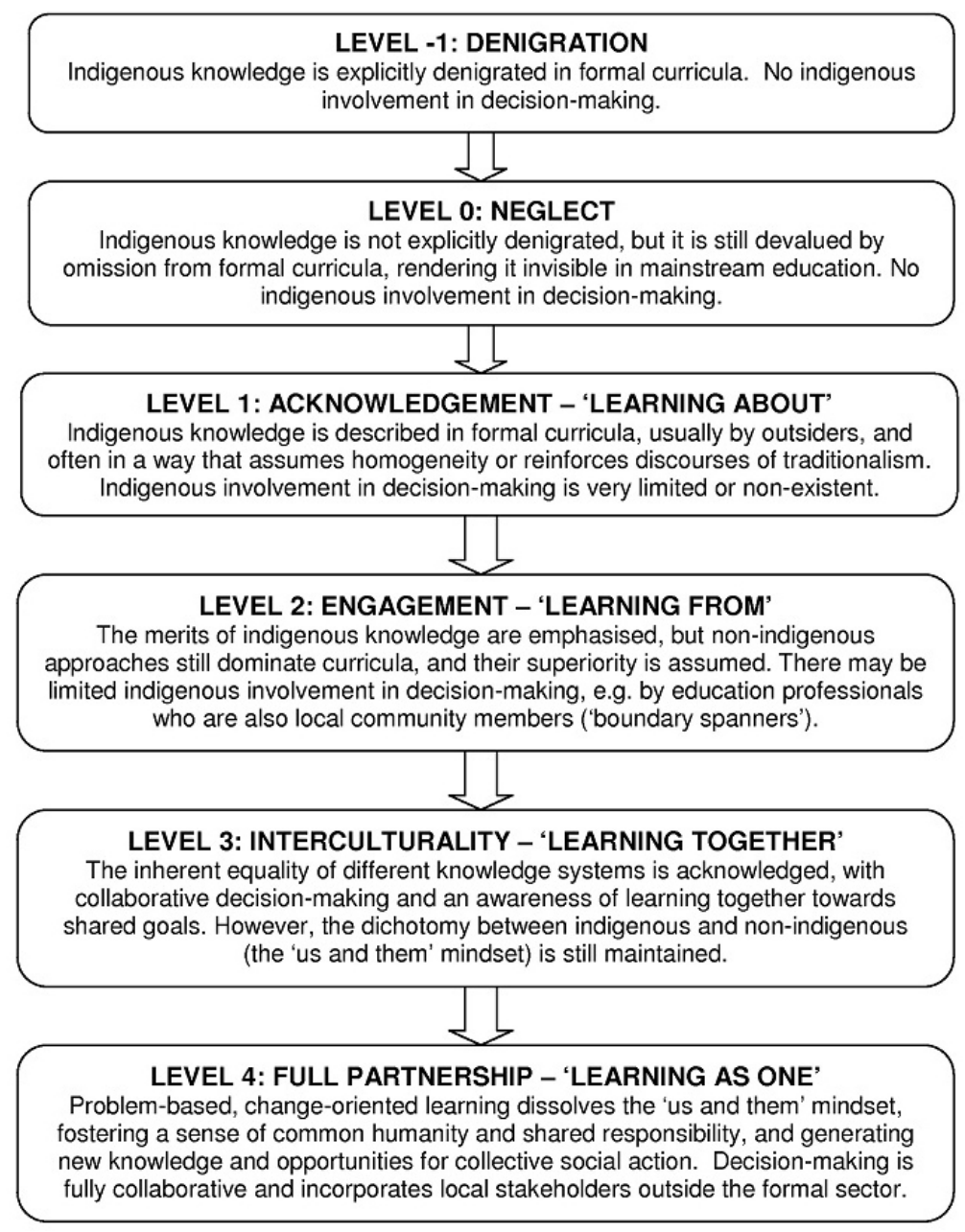

staff. A study has recently been launched to compare the ethnobotanical knowledge of participating students and nonparticipating Maasai youth of a similar age within the local area.

\section{DISCUSSION}

\section{Toward a conceptual framework of participation in intercultural education}

Both of our examples simultaneously illustrate depth, breadth, and scope of local participation. An important observation in both examples is the presence of individuals who are members of multiple constituencies such as indigenous community members who are employed as education professionals. These individuals take on a boundary-spanner role: translating between partners, aligning differing world-views, and helping to resolve any conflicts arising at the interface between knowledge systems (Wenger 1998, Hart et al. 2007). This role can also be played by professionals trained in facilitation and conflict resolution, as illustrated by the UIMQRoo model, in which all students are required to take a course in these subjects, and in which a culture of facilitation is actively pursued in all meetings.

We can construct a novel ladder of participation (Arnstein 1969) to describe different levels of indigenous participation in educational initiatives, using curriculum content and indigenous involvement in decision making as complementary indicators of participation depth. We distinguish the acknowledgement (learning about) and engagement (learning from) approaches, described above, from interculturality (learning together) and full partnership (learning as one) models illustrated in the examples (Fig. 1). 
Table 1. Key decision-making stages in intercultural education.

\begin{tabular}{|c|c|c|}
\hline Decision-making stage & $\begin{array}{l}\text { Definition in participatory evaluation literature } \\
\text { (Daigneault and Jacob 2009) }\end{array}$ & New definition for intercultural education \\
\hline 1. Initiation & Set questions and issues for evaluation and definition & Identify needs and goals \\
\hline 2. Design & Design the methodology [of evaluation] & Design the curricula and research projects \\
\hline 3. Implementation & Collect and analyze data & Implement teaching, facilitation, and/or research activities \\
\hline 4. Reflection & Formulate judgments and recommendations & Assess individual projects and evaluate overall program \\
\hline 5. Communication & Report and disseminate evaluation findings & $\begin{array}{l}\text { Communicate findings and achievements (e.g., to policy makers, } \\
\text { donors, prospective students, and/or the general public) }\end{array}$ \\
\hline
\end{tabular}

The UIMQRoo model illustrates what we have termed level 3 (learning together) and is approaching level 4 (full partnership), although some challenges of professional certification for sabios locales remain. At Noonkodin, the intercultural program itself similarly exemplifies level 3 . Importantly, however, this program has no official recognition or accreditation and is taught separately from the national curriculum. The dichotomy between indigenous and nonindigenous knowledge is maintained, with the latter afforded higher status by students and staff because it leads to recognized qualifications. We can thus rate overall participation depth, across the whole school, as level 2 (learning from indigenous knowledge).

Breadth of participation is demonstrated in the efforts of both institutions to engage with the wider community by promoting student research projects that are directed by local needs and priorities. Following Daigneault and Jacob (2009), we can identify four broad categories of relevant stakeholders: policy makers, implementers (educators), beneficiaries (students), and civil society (local communities). However, identifying indigenous stakeholders is complicated by the existence of boundary spanners in each category, rendering direct comparisons of participation breadth nearly impossible. Nonetheless, an important observation is that in Mexico, there is extensive participation in intercultural education by policy makers and other key decision makers, especially at the dissemination stage. However, in Tanzania, the intercultural program is unaccredited, and participation of decision makers is extremely limited. We speculate that the respective political and historical contexts of conservation in Mexico and Tanzania might be an important factor underlying this difference.

Scope of participation refers to the number of key stages in which certain individuals, or categories of individuals, are actively engaged in decision making. By analogy with Daigneault and Jacob (2009), we propose that an intercultural education program can be understood to consist of five distinct stages: (1) initiation (identification of need); (2) design (construction of curricula and/or problem-centered learning exercises); (3) implementation of teaching, facilitation, and/ or research activities; (4) reflection (individual assessment and overall program evaluation); and (5) communication of program outputs, e.g., to policy makers, donors, prospective students, and the public (Table 1).

At UIMQRoo, community members outside the formal education sector are involved in student projects at all five stages. At Noonkodin, conversely, community elders (with the exception of boundary spanners) participate actively at the implementation stage but have limited involvement in other stages (Table 2).

\section{Evaluating intercultural education}

We have presented preliminary evidence supporting the argument that intercultural education can make important contributions to resource management and biocultural diversity conservation. Recent graduates of the UIMQRoo program are incorporating their learning extensively into public sector development and conservation programs. At Noonkodin, medicinal plant knowledge is being rigorously documented and acquired by younger generations. A systematic approach to monitoring and evaluation is now needed in both cases, not only to deepen understanding of these outcomes, but also to evaluate the third broad goal of knowledge integration: achievement of social justice.

One evaluative approach that may prove helpful in this respect is utilization-focused evaluation, which demands explicit consideration of who the evaluation is for and what they intend to do with it (Patton 1999, Donaldson et al. 2010). At its best, utilization-focused evaluation can become an iterative process incorporating reflective learning and feedback loops at all stages (Crohn and Birnbaum 2010, Flowers 2010), which appears ideally suited to intercultural education. The Noonkodin example also illustrates the potential of localizable values-based indicators (Podger et al. 2010, Burford et al. 2013) for the evaluation of intangible justice-related outcomes of intercultural education such as strengthening democracy, enhancing mutual respect, or empowering indigenous youth, which may be problematic to assess through conventional methods. A similar approach is now being developed at UIMQRoo, learning from the Tanzanian experience and adapting it to the new context. 
Table 2. Qualitative description of participation by indigenous stakeholders in students' field research projects in Mexico and Tanzania.

\begin{tabular}{|c|c|c|}
\hline Decision-making stage & Intercultural Maya University of Quintana Roo, Mexico & Noonkodin Secondary School, Tanzania \\
\hline $\begin{array}{l}\text { 1. Initiation (identification of } \\
\text { needs and goals) }\end{array}$ & $\begin{array}{l}\text { Student projects are initiated collaboratively by Maya } \\
\text { community members (both within and outside the formal } \\
\text { education system) and students, focusing on local needs } \\
\text { and priorities }\end{array}$ & $\begin{array}{l}\text { Student projects are initiated collaboratively by Maasai } \\
\text { community members (within the formal education system } \\
\text { only), visiting interns, and students, toward the global goal of } \\
\text { biocultural diversity conservation }\end{array}$ \\
\hline 2. Design of research & $\begin{array}{l}\text { A participatory approach is taken, allowing for input from } \\
\text { community members (within and outside the formal } \\
\text { education system) and students, focusing on local needs } \\
\text { and priorities }\end{array}$ & $\begin{array}{l}\text { Research methods are selected by two Maasai staff members } \\
\text { in boundary spanner roles (part-time project coordinator and } \\
\text { full-time environmental studies teacher) in consultation with } \\
\text { visiting interns }\end{array}$ \\
\hline 3. Implementation of research & $\begin{array}{l}\text { Community members (within and outside the formal } \\
\text { education system) act as key informants and guide the } \\
\text { implementation of student research projects }\end{array}$ & $\begin{array}{l}\text { The project coordinator and environmental studies teacher } \\
\text { (see above) assist students with data collection and analysis. } \\
\text { Community members outside the formal education system, e. } \\
\text { g., Maasai herbalists, act as key informants but do not } \\
\text { provide implementation advice }\end{array}$ \\
\hline $\begin{array}{l}\text { 4. Reflection (individual } \\
\text { project assessment and/or } \\
\text { overall program evaluation) }\end{array}$ & $\begin{array}{l}\text { Community members (within and outside the formal } \\
\text { education system) and sabios locales, who have equivalent } \\
\text { status to formally trained faculty, participate in assessing } \\
\text { the individual research projects }\end{array}$ & $\begin{array}{l}\text { Individual research projects are assessed by the } \\
\text { environmental studies teacher; values-based indicators for } \\
\text { program evaluation are selected by a visiting intern after } \\
\text { consultation with the project coordinator }\end{array}$ \\
\hline $\begin{array}{l}\text { 5. Communication of findings } \\
\text { and achievements }\end{array}$ & $\begin{array}{l}\text { Diverse stakeholders within the wider community (which } \\
\text { includes local rural community members, sabios locales, } \\
\text { the university, government and nongovernmental } \\
\text { organization funders of projects, and professionals with } \\
\text { relevant expertise) are all involved, as appropriate, in } \\
\text { disseminating research findings and applying them to } \\
\text { practical problems }\end{array}$ & $\begin{array}{l}\text { Very limited dissemination to date; the head teacher of the } \\
\text { school (also ethnically Maasai, i.e., a boundary spanner) is } \\
\text { planning to present evaluation findings at a forthcoming } \\
\text { regional education conference, which may open up new } \\
\text { opportunities for engagement with policy makers at local and } \\
\text { national levels }\end{array}$ \\
\hline
\end{tabular}

\section{CONCLUSION}

We have highlighted several important features of intercultural education in indigenous communities that were not previously described. We have developed and shown the usefulness of a ladder that indicates different levels of indigenous participation in education. In its optimal form, intercultural education exemplifies the deepest level of participation, namely full partnership, which constitutes a new development in the evolution of relations between indigenous and nonindigenous communities within the educational realm. Full partnership entails the dissolution of dichotomies between the indigenous and the nonindigenous (e.g., through problembased learning that generates new knowledge to meet common goals). Other important dimensions of participation are its scope (i.e., the number of key project stages in which a particular stakeholder group is participating), and its breadth, or stakeholder diversity.

This conceptual framework provides a means of comparing participation across very different contexts, from a large state- and federally funded university in Mexico to an unaccredited program led by a small nongovernmental organization in Tanzania. Participation theory can thus provide a bridge between conservation and development in Africa and Latin America, opening up new vistas for future research. Although policy makers in Africa have much to learn from the Latin American experience of bringing intercultural education into the mainstream, there are also lessons to be learned from Africa, as illustrated by the transfer of values-based evaluation from Tanzania to Mexico.

We have linked three distinct goals of knowledge integration (Bohensky and Maru 2011) to intercultural education: adaptive co-management, biocultural diversity conservation, and social justice. Our provisional findings suggest that at least two of these were achieved in the projects studied, although a systematic approach to evaluation is now required. 
Responses to this article can be read online at: http://www.ecologyandsociety.org/issues/responses. $\mathrm{php} / 5250$

\section{Acknowledgments:}

We thank the organizers of the 2010 Tropical Conservation and Development Conference at the University of Florida for fostering this productive collaboration. We also acknowledge the patient mentoring of the guest editors of this special feature and the helpful suggestions provided by anonymous reviewers. We are grateful to Sam van Boeckel, Naomi Becht, W. Jo-An Ho, Musa Kamaika, Maartje Melse, Grosper Mollel, Leboy Oltimbau, Kephas Ndiamasi, Charley Nussey, Professor Lori Stanley, and Jona Walk for their substantial contributions to the Intercultural Education Research Programme at Noonkodin Secondary School, Eluwai, Tanzania, which inspired Gemma Burford's conference presentation and the original draft of this article.

\section{LITERATURE CITED}

Adams, J. S., and T. O. McShane. 1992. The myth of wild Africa: conservation without illusion. W. W. Norton, New York, New York, USA.

Agrawal, A. 1995. Dismantling the divide between indigenous and scientific knowledge. Development and Change 26 (3):413-439. http://dx.doi.org/10.1111/j.1467-7660.1995.tb00560. $\underline{\mathrm{X}}$

Aguilar Pérez, M. G., and Ortega Pérez. 2008. Razonamiento y aprendizaje en educación superior: estudio de caso. Plaza y Valdés, Madrid, Spain.

Aikman, S. 1997. Interculturality and intercultural education: a challenge for democracy. International Review of Education 43(5-6):463-479. http://dx.doi.org/10.1023/A:1003042105676

Aikman, S. 1998. Towards an intercultural participatory approach to learning for the Harakmbut. International Journal of Educational Development 18(3):197-206. http://dx.doi. org/10.1016/S0738-0593(98)00032-7

Armitage, D., M. Marschke, and R. Plummer. 2008. Adaptive co-management and the paradox of learning. Global Environmental Change 18(1):86-98. http://dx.doi.org/10.1016/ j.gloenvcha.2007.07.002

Arnold, J. S., and M. Fernandez-Gimenez. 2007. Building social capital through participatory research: an analysis of collaboration on Tohono O'odham tribal rangelands in Arizona. Society and Natural Resources 20(6):481-495. http:// dx.doi.org/10.1080/08941920701337887
Arnstein, S. R. 1969. A ladder of citizen participation. Journal of the American Institute of Planners 35(4):216-224. http:// dx.doi.org/10.1080/01944366908977225

Assies, W. 2008. Land tenure and tenure regimes in Mexico: an overview. Journal of Agrarian Change 8(1):33-63. http:// dx.doi.org/10.1111/j.1471-0366.2007.00162.x

Ataöv, A., B. Brøgger, and J. M. Hildrum. 2010. An action research approach to the inclusion of immigrants in work life and local community life: preparation of a participatory realm. Action Research 8(3):237-265. http://dx.doi.org/10.1177/14$\underline{76750309335209}$

Becht, N. M., and J.-A. Ho. 2009. The future of Maasai indigenous medicinal knowledge: an analysis of Noonkodin's Secondary School students' knowledge on medicinal plants compared to that of elderly traditional health professionals. Internship report. University College Utrecht, Utrecht, The Netherlands.

Berkes, F., J. Colding, and C. Folke. 2000. Rediscovery of traditional ecological knowledge as adaptive management. Ecological Applications 10(5):1251-1262. http://dx.doi. org/10.1890/1051-0761(2000)010[1251:ROTEKA]2.0.CO;2

Biggs, S. 1989. Resource-poor farmer participation in research: a synthesis of experiences from nine national agricultural research systems. OFCOR Comparative Study 3. International Service for National Agricultural Research, The Hague, The Netherlands.

Bodeker, G., and G. Burford. 2008. Traditional knowledge and spas. Pages 414-431 in M. Cohen and G. Bodeker, editors. Understanding the global spa industry: spa management. Elsevier, Oxford, UK.

Bodnar, Y. 1990. Aproximación a la etnoeducación como elaboración teorica. In Etnoeducación: conceptualización y ensayos. Programa de Etnoeducación PRODIC, Ministry of Education, Bogota, Colombia.

Bohensky, E. L., and Y. Maru. 2011. Indigenous knowledge, science, and resilience: what have we learned from a decade of international literature on "integration"? Ecology and Society 16(4): 6. http://dx.doi.org/10.5751/ES-04342-160406

Boud, D., and G. Feletti. 1998. The challenge of problembased learning. Second edition. Routledge, London, UK.

Burford, G. 2002. Linking healthcare and natural resource management: the ritual of olpul among Ilkisongo Maasai in Monduli District, Tanzania. Dissertation. University of Kent, Canterbury, UK.

Burford, G., and L. Ole Ngila. 2006. Intercultural education in a Tanzanian secondary school. COMPAS Magazine 
10:15-17. [online] URL: http://www.compasnet.org/afbeeldingen/ Magazines/CM10/cm10 07.pdf.

Burford, G., L. Ole Ngila, and Y. Rafiki. 2003. Education, indigenous knowledge and globalisation. Science in Africa 21. [online] URL: http://www.scienceinafrica.co.za/2003/march/ ik.htm.

Burford, G., I. Velasco, S. Janousková, M. Zahradnik, T. Hak, D. Podger, G. Piggot, and M. K. Harder. 2013. Field trials of a novel toolkit for evaluating 'intangible' values-related dimensions of projects. Evaluation and Program Planning 36 (1), in press. http://dx.doi.org/10.1016/j.evalprogplan.2012.04.005

Campbell, B., and L. Marshall. 2003. Re-presenting indigenous knowledges: learning about or learning from? International Journal of Learning 10:2373-2384.

Carignan, N., R. G. Pourdavood, L. C. King, and N. Feza. 2005. Social representations of diversity: multi/intercultural education in a South African urban school. Intercultural Education 16(4):381-393. http://dx.doi.org/10.1080/146759$\underline{80500304371}$

Casillas-Muñoz, M. L., and L. S. Villar. 2006. Universidad intercultural: modelo educativo. Coordinación General de Educación Intercultural y Bilingüe, Mexico City, Mexico.

Castleden, H., T. Garvin, and Huu-ay-aht First Nation. 2008 Modifying Photovoice for community-based participatory Indigenous research. Social Science and Medicine 66 (6):1393-1405. http://dx.doi.org/10.1016/j.socscimed.2007.11.030

Chambers, R. 1997. Whose reality counts? Putting the first last. Intermediate Technology, London, UK.

Cornwall, A., and R. Jewkes. 1995. What is participatory research? Social Science and Medicine 41(12):1667-1676. http://dx.doi.org/10.1016/0277-9536(95)00127-S

Cousins, J. B., J. J. Donohue, and G. A. Bloom. 1996. Collaborative evaluation in North America: evaluators' selfreported opinions, practices and consequences. Evaluation Practice 17(3):207-226. http://dx.doi.org/10.1177/1098214$\underline{09601700302}$

Cousins, J. B., and E. Whitmore. 1998. Framing participatory evaluation. New Directions for Evaluation 80:5-23.

Crishna, B. 2007. Participatory evaluation (I) - sharing lessons from fieldwork in Asia. Child: Care, Health and Development 33:217-223. http://dx.doi.org/10.1111/ j.1365-2214.2006.00657.x

Crohn, K., and M. Birnbaum. 2010. Environmental education evaluation: time to reflect, time for change. Evaluation and Program Planning 33(2):155-158. http://dx.doi.org/10.1016/ j.evalprogplan.2009.07.004
Cross, M. 2004. Institutionalising campus diversity in South African higher education: review of diversity scholarship and diversity education. Higher Education 47(4):387-410. http:// dx.doi.org/10.1023/B:HIGH.0000020854.04852.80

Daigneault, P.-M., and S. Jacob. 2009. Toward accurate measurement of participation: rethinking the conceptualization and operationalization of participatory evaluation. American Journal of Evaluation 30(3):330-348. http://dx.doi. org $/ 10.1177 / 1098214009340580$

de Janvry, A., M. Fafchamps, and E. Sadoulet. 1991. Peasant household behaviour with missing markets: some paradoxes explained. Economic Journal 101(409):1400-1417. http://dx. doi.org/10.2307/2234892

Donaldson, S. I., M. Q. Patton, D. M. Fetterman, and M. Scriven. 2010. The 2009 Claremont Debates: the promise and pitfalls of utilization-focused and empowerment evaluation. Journal of MultiDisciplinary Evaluation 6(13):15-57.

Ellen, R. 1998. Response to Paul Sillitoe, "The development of indigenous knowledge: a new applied anthropology". Current Anthropology 39(2):238-239.

Ellis, E. A., and L. Porter-Bolland. 2008. Is community-based forest management more effective than protected areas?: A comparison of land use/land cover change in two neighboring study areas of the Central Yucatan Peninsula, Mexico. Forest Ecology and Management 256(11):1971-1983. http://dx.doi. org/10.1016/j.foreco.2008.07.036

Fine, L. 2008. The legacy of national parks: community-based conservation in Tanzania and Zimbabwe. Undergraduate thesis. Boston University Academy, Boston, Massachusetts, USA. [online] URL: http://www.lulu.com/items/ volume_63/2491000/2491737/1/print/leah_fine.pdf.

FitzGerald, J. R. S. 2008. The last of the Maasai in northern Tanzania? Redefining cultural identity. Dissertation. Oxford Brookes University, Oxford, UK.

Flowers, A. B. 2010. Blazing an evaluation pathway: lessons learned from applying utilization-focused evaluation to a conservation education program. Evaluation and Program Planning 33(2):165-171. http://dx.doi.org/10.1016/j. evalprogplan.2009.07.006

Rodríguez Gabarrón, L., and L. Hernández Landa. 1994. Investigación participativa. Cuadernos Metodológicos 10. Centro de Investigaciones Sociológicas, Madrid, Spain.

García, M. E. 2005. Making indigenous citizens: identities, education, and multicultural development in Peru. Stanford University Press, Stanford, California, USA.

Geoghegan, J., S. Cortina Villar, P. Klepeis, P. Macario Mendoza, Y. Ogneva-Himmelberger, R. R. Chowdhury, B. L. 
Turner II, and C. Vance. 2001. Modeling tropical deforestation in the southern Yucatan peninsular region: comparing survey and satellite data. Agriculture, Ecosystems and Environment 85(1-3):25-46. http://dx.doi.org/10.1016/S0167-8809(01)00201-8

Gibbons, M., C. Limoges, H. Norwotony, S. Schwarzman, P. Scott, and M. Trow. 1994. The new production of knowledge: the dynamics of science and research in contemporary societies. Sage, London, UK.

Gliessman, S. R. 2007. Agroecology: the ecology of sustainable food systems. Second edition. CRC Press, Boca Raton, Florida, USA.

Goldman, M. 2001. Partitioned nature, privileged knowledge: community based conservation in the Maasai ecosystem, Tanzania. Environmental Governance in Africa Working Paper 3. World Resources Institute, Washington, D.C., USA. [online] URL: http://pdf.wri.org/eaa wp3.pdf.

Gundara, J. S. 2000. Interculturalism, education and inclusion. Paul Chapman, London, UK.

Håkansson, A.-K. 2001. Roots of life: cultural diversity for sustainable development. An indigenous approach. NarvaTryckeriet, Stockholm, Sweden.

Hanley, B., J. Bradburn, M. Barnes, C. Evans, H. Goodare, M. Kelson, A. Kent, S. Oliver, S. Thomas, and J. Wallcraft. 2004. Involving the public in NHS, public health, and social care research: briefing notes for researchers. Second edition. INVOLVE, Eastleigh, UK. [online] URL: http://www. twocanassociates.co.uk/perch/resources/files/Briefing\%20Note\% 20Final_dat(2).pdf.

Hart, A., E. Maddison, and D. Wolff. 2007. Introduction. Pages 3-7 in A. Hart, E. Maddison, and D. Wolff, editors. Community-university partnerships in practice. National Institute of Adult Continuing Education, Leicester, UK.

Hart, R. A. 1992. Children's participation: from tokenism to citizenship. UNICEF International Child Development Centre, Florence, Italy. [online] URL: http://www.unicef-irc. org/publications/100.

Hodgson, D. L. 2005. The church of women: gendered encounters between Maasai and missionaries. Indiana University Press, Bloomington, Indiana, USA.

Honeyman, C. A. 2010. Social responsibility and community development: lessons from the Sistema de Aprendizaje Tutorial in Honduras. International Journal of Educational Development 30(6):599-613. http://dx.doi.org/10.1016/j. ijedudev.2010.02.004

Bradbury-Huang, H. 2010. What is good action research?: Why the resurgent interest? Action Research 8(1):93-109. http://dx.doi.org/10.1177/1476750310362435
Igoe, J. 2010. The spectacle of nature in the global economy of appearances: anthropological engagements with the spectacular mediations of transnational conservation. Critique of Anthropology 30(4):375-397. http://dx.doi.org/10.1177/0$\underline{308275 X 10372468}$

Igoe, J., and B. Croucher. 2007. Conservation, commerce, and communities: the story of community-based wildlife management areas in Tanzania's northern tourist circuit. Conservation and Society (5)5:534-561.

Ivaska, A. M. 2004. "Anti-mini militants meet modern misses": urban style, gender, and the politics of "national culture" in 1960s Dar es Salaam, Tanzania. Pages 104-124 in J.M. Allman, editor. Fashioning Africa: power and the politics of dress. Indiana University Press, Bloomington, Indiana, USA.

Kainer, K. A., M. L. DiGiano, A. E. Duchelle, L. H. O. Wadt, E. Bruna, and J. L. Dain. 2009. Partnering for greater success: local stakeholders and research in tropical biology and conservation. Biotropica 41(5):555-562. http://dx.doi. org/10.1111/j.1744-7429.2009.00560.x

Klooster, D. J. 2002. Toward adaptive community forest management: integrating local forest knowledge with scientific forestry. Economic Geography 78(1):43-70. http:// dx.doi.org/10.1111/j.1944-8287.2002.tb00175.x

Laing, S., and E. Maddison. 2007. The Cupp model in context. Pages 8-20 in A. Hart, E. Maddison, and D. Wolff, editors. Community-university partnerships in practice. National Institute of Adult Continuing Education, Leicester, UK.

MacLean, S., D. Warr, and P. Pyett. 2009. Was it good for you too? Impediments to conducting university-based collaborative research with communities experiencing disadvantage. Australian and New Zealand Journal of Public Health 33 (5):407-412. http://dx.doi.org/10.1111/j.1753-6405.2009.00420. $\underline{x}$

Maffi, L., editor. 2001. On biocultural diversity: linking language, knowledge and the environment. Smithsonian Institution Press, Washington, D.C., USA.

Maffi, L., and E. Woodley. 2010. Biocultural diversity conservation: a global sourcebook. Earthscan, London, UK.

Martin, G. J. 2004. Ethnobotany: a methods manual. Earthscan, London, UK.

McCabe, J. T. 2003. Sustainability and livelihood diversification among the Maasai of northern Tanzania. Human Organization (2):100-111.

Moller, H., F. Berkes, P. O. Lyver, and M. Kislalioglu. 2004. Combining science and traditional ecological knowledge: monitoring populations for co-management. Ecology and 
Society 9(3): 2. [online] URL: http://www.ecologyandsociety. org/vol9/iss3/art2/.

Murphy-Graham, E. 2007. Promoting participation in public life through secondary education: evidence from Honduras. Prospects: Quarterly Review of Comparative Education 37 (1):95-111. http://dx.doi.org/10.1007/s11125-007-9013-2

Naylor, P.-J., J. Wharf-Higgins, L. Blair, L. Green, and B. O'Connor. 2002. Evaluating the participatory process in a community-based heart health project. Social Science and Medicine 55(7):1173-1187. http://dx.doi.org/10.1016/S0277-9536 $\underline{(01) 00247-7}$

Ndagala, D. K. 1982. 'Operation Imparnati': the sedentarization of the pastoral Maasai in Tanzania. Nomadic Peoples 10:28-39. [online] URL: http://cnp.nonuniv.ox.ac.uk/ pdf/NP journal back issues/Operation Impartnati DK Ndagala. pdf.

Ninnes, P. 2000. Representations of indigenous knowledges in secondary school science textbooks in Australia and Canada. International Journal of Science Education 22 (6):603-617. http://dx.doi.org/10.1080/095006900289697

Ojating, I. 1997. Folklore and conservation in Nigeria: using PRA to learn from the elders. PLA Notes 28:22-24. [online] URL: http://www.planotes.org/documents/plan 02805.PDF.

Patton, M. Q. 1999. Utilization-focused evaluation in Africa. Training sessions delivered to the inaugural conference of the African Evaluation Association, 13-17 September 1999, Nairobi, Kenya. [online] URL: http://preval.org/documentos/00552. pdf.

Patton, M. Q. 2008. Utilization-focused evaluation: the new century text. Fourth edition. Sage, Thousand Oaks, California, USA.

Pedota, L. 2011. Indigenous intercultural universities in Latin America: interpreting interculturalism in Mexico and Bolivia. Thesis. Loyola University, Chicago, Illinois, USA. [online] URL: http://ecommons.luc.edu/luc theses/516.

Pérez Tamayo, R. 1998. ¿Existe él método científico? Historia $y$ realidad. Third edition. Fondo de Cultura Económica, Mexico City, Mexico. [online] URL: http://bibliotecadigital. ilce.edu.mx/sites/ciencia/volumen3/ciencia3/161/html/metodo. html.

Peterson, J. C. 2010. CBPR in Indian Country: tensions and implications for health communication. Health Communication 25(1):50-60. http://dx.doi.org/10.1080/10410230903473524

Podger, D., G. Piggot, M. Zahradnik, S. Janousková, I. Velasco, T. Hak, A. Dahl, A. Jimenez, and M. K. Harder. 2010. The Earth Charter and the ESDinds Initiative: developing indicators and assessment tools for civil society organisations to examine the values dimensions of sustainability projects.
Journal of Education for Sustainable Development 4 (2):297-305. http://dx.doi.org/10.1177/097340821000400219

Powers, J., S. A. Cumbie, and D. Weinert. 2006. Lessons learned through the creative and iterative process of community-based participatory research. International Journal of Qualitative Methods 5(2):120-130.

Primack, R. B., D. Bray, H. A. Galletti, and I. Ponciano, editors. 1999. La selva Maya, conservación y desarrollo. Siglo XXI Editores, Mexico City, Mexico.

Reed, M. S., and A. J. Dougill. 2002. Participatory selection process for indicators of rangeland condition in the Kalahari. Geographical Journal 168:224-234.

Romero, C., and M. Peña-Claros. 2009. Beyond tropical forests adoption: contextualizing conservation strategies. Biotropica 41(6):653-655. http://dx.doi.org/10.1111/ j.1744-7429.2009.00582.x

Ruitenbeek, J., and C. Cartier. 2001. The invisible wand: adaptive co-management as an emergent strategy in complex bio-economic systems. Occasional Paper 34. Center for International Forestry Research, Bogor, Indonesia. [online] URL: http://www.cifor.org/publications/pdf files/OccPapers/ OP-034.pdf.

Sachedina, H. T. 2008. Wildlife is our oil: conservation, livelihoods and NGOs in the Tarangire ecosystem, Tanzania. Dissertation. University of Oxford, Oxford, UK. [online] URL: http://african-environments.ouce.ox.ac.uk/pdf/sachedina dphil. pdf.

Schmelkes, S. 2009. Intercultural universities in Mexico: progress and difficulties. Intercultural Education 20(1):5-17. http://dx.doi.org/10.1080/14675980802700649

Schmook, B., and C. Vance. 2009. Agricultural policy, market barriers, and deforestation: the case of Mexico's southern Yucatán. World Development 37(5):1015-1025. http://dx.doi. org/10.1016/j.worlddev.2008.09.006

Schneider, L. 2006. The Maasai's new clothes: a developmentalist modernity and its exclusions. Africa Today 53(1):101-131. http://dx.doi.org/10.1353/at.2006.0063

Schroder, B. 2006. Native science, intercultural education and place-conscious education: an Ecuadorian example. Educational Studies 32(3):307-317. http://dx.doi. org/10.1080/03055690600845438

Scott, J. C. 1998. Seeing like a state: how certain schemes to improve the human condition have failed. Yale University Press, New Haven, Connecticut, USA.

Sillitoe, P. 1998. The development of indigenous knowledge: a new applied anthropology. Current Anthropology 39 (2):223-252. http://dx.doi.org/10.1086/204722 
Taiepa, T., P. Lyver, P. Horsley, J. Davis, M. Brag, and H. Moller. 1997. Co-management of New Zealand's conservation estate by Maori and Pakeha: a review. Environmental Conservation 24(3):236-250. http://dx.doi. org/10.1017/S0376892997000325

United Nations Environment Program. 2003. Traditional lifestyles and biodiversity use. Regional report: Africa. Composite report on the status and trends regarding the knowledge, innovations and practices of indigenous and local communities relevant to the conservation and sustainable use of biodiversity. UNEP World Conservation Monitoring Centre, Cambridge, UK. [online] URL: www.cbd.int/doc/ meetings/tk/wg8j-03/information/wg8j-03-inf-03-en.doc.

Wenger, E. 1998. Communities of practice: learning, meaning, and identity. Cambridge University Press, Cambridge, UK.

Zent, S. 2001. Acculturation and ethnobotanical knowledge among the Piaroa of Venezuela: demonstration of a quantitative method for the empirical study of traditional ecological knowledge change. Pages 190-211 in L. Maffi, editor. On biocultural diversity: linking language, knowledge and the environment. Smithsonian Institution Press, Washington, D.C., USA. 